\title{
Pemanfaatan Limbah Konstruksi menjadi Villa Serbaguna dengan Pendekatan Green Design
}

\author{
Felicia Wisama $^{1}$, Febriani Elisabeth ${ }^{2}$, Indah Fahroni ${ }^{3}$ \\ 1,2,3 Jurusan Desain Interior, Universitas Kristen Petra, Surabaya \\ Jln. Siwalankerto No. 121-131, Siwalankerto, Kec. Wonocolo, Kota Surabaya, Jawa Timur, 60236 \\ m41416112@john.petra.ac.id¹,m41416083@john.petra.ac.id²
}

\begin{abstract}
ABSTRAK
Bidang arsitektur maupun interior telah berkembang begitu pesat, mengikuti perkembangan trend zaman ini. Sehingga memicu masyarakat untuk berlomba-lomba dalam memperindah hunian mereka. Namun, seringkali material yang digunakan dalam jumlah besar, kurang dimanfaatkan secara optimal. Hal ini menyebabkan produksi limbah bangunan dalam skala yang besar, padahal limbah-limbah tersebut masih memiliki nilai guna. Di sisi lain, jika material sisa bangunan hanya disimpan begitu saja tanpa diolah lagi, maka biaya yang dikeluarkan akan membengkak. Tentu saja, material sisa yang melimpah bisa menjadi persoalan utama bagi beberapa orang. Oleh karena itu di zaman sekarang ini, telah berkembang berbagai inovasi dalam dunia arsitektur yang berpotensi sebagai solusi. Salah satu inovasi yang sedang diminati masyarakat akhir-akhir ini adalah konsep Green Design, dimana meliputi aspek zerowaste, recycle serta memaksimalkan penghawaan alami. Penulisan karya tulis ini bertujuan untuk memaparkan penelitian tentang pengolahan limbah material menjadi bangunan serbaguna, dengan pendekatan Green Design. Metode yang digunakan adalah pendekatan kualitatif deskriptif yang digabungkan dengan tahapan design thinking sehingga dapat mengimbangi kebutuhan pengunjung. Dengan adanya penelitian ini, diharapkan selain dapat menjadi peluang usaha yang berpotensi dan bernilai jual bagi para konsumen, juga dapat mengatasi permasalahan limbah yang ada di lingkungan sekitar.
\end{abstract}

Kata kunci: villa; limbah; zerowaste; recycle; green design

\section{ABSTRACT}

Architecture and interior have grown rapidly, following the development of current trend. It triggers the people to compete in terms of making their residence beautiful. But, often the material that was in a big amout, was not optimally used. This results in the production of large scale building waste, even though those wastes can still be used. On the other hand, if the waste building material only being stored without further processing. Then the cost incurred will swell. Of course the abundant waste material can be a major problem for some people. That alis way in this time and age, various innovation are developing in the architecture world that have potential as solution. One of those innovation that people are interested in lately is the design concept of Green design in which covers the zerowaste, recycle aspect and also maximize natural air. This writing of this paper aims to explain processing waste materials into multipurpose buildings with a green design approach. The method used is a qualitative description approach which combine with design thinking stage so that it could offset the needs of visitors. With this research it is hoped that in addition to being a potential and valuable business opportunity for consumers, it can also overcome waste problems in the surrounding environment.

Keyword: villa, wastes, zerowaste, recycle, green design

\section{PENDAHULUAN}

Perkembangan dunia arsitektur dan desain interior mengalami perubahan yang sangat pesat, terutama pada hal trendy masyarakat berlomba-lomba memperbaiki rumah mereka dengan bermacam desain yang kekinian. Untuk menciptakan arsitektur bangunan yang trendy para arsitektur harus menggunakan material konstruksi dengan jumlah yang cukup banyak, 
material yang dimaksudkan seperti penggunaan kayu, besi, dan batu-batuan dalam jumlah sangat banyak sehingga setiap pemrosesan material akan menghasilkan limbah konstruksi yang sangat banyak.

Limbah yang dihasilkan dalam jumlah yang banyak dapat menyebabkan pencemaran lingkungan, yang nantinya akan merugikan manusia dan juga ekosistem disekitarnya. Tetapi masih ada beberapa orang yang peduli dengan cara menyimpan limbah bekas konstruksinya dalam sebuah gudang persewaan. Hal ini terkadang menjadi permasalahan dikarenakan butuh budget khusus untuk menyewa gudang penyimpanan barang pengelolaan limbah konstruksi yang dibutuhkan. Kegiatan penyimpanan ini dimaksudkan sebagai upaya pengurangan limbah, dan memanfaatkannya kembali.

Tidak semua limbah terbarukan dapat dimanfaatkan kembali kedalam perancangan bangunan, tetapi ada beberapa limbah yang masih bisa digunakan. Salah satu contoh limbah yang dapat digunakan kembali adalah besi, potongan dan lembaran kayu. Pemilihan limbah jenis ini juga berguna untuk memanfaatkan kembali material yang sudah tidak bisa digunakan menjadi barang yang memiliki nilai guna tinggi. Pada era sekarang ini, dunia arsitektur telah berkembang pesat dan memunculkan berbagai inovasi yang berpotensi sebagai solusi penyelesaian dalam bidang desain, salah satu inovasi yang sedang diminati masyarakat akhirakhir ini adalah inovasi desain dengan konsep green design, dimana meliputi aspek zerowaste, recycle serta memaksimalkan penghawaan alami.

Terdapat banyak bangunan yang menggunakan konsep green design dengan pemanfaatan limbah konstruksi ini satunya adalah sebuah villa yang terletak di kota Sarangan. Villa ini didirikan dengan tujuan untuk mengurangi limbah yang dapat merusak lingkungan selain itu villa ini dapat dimanfaatkan untuk keluarga atau kerabat yang ingin menginap di villa dengan view pengunungan. Sebagian orang masih terasa asing untuk memanfaatkan material bekas menjadi material utama suatu hunian, namun jika diterapkan dalam interior dapat memberikan kesan industrial, nyaman dan menarik. Villa ini hampir 90\% menggunakan material limbah konstruksi yang tidak di finishing sehingga memiliki kesan Pure Material. Menggunakan material tanpa finishing memberikan kesan berbeda beda kepada pengguna ruang yang ditimbulkan oleh faktor limbah bekas konstruksi ini karena warna dan suasana ruang yang diciptakan.

\section{METODE PENELITIAN}

\section{A. Metode Pengumpulan Data}

Metode pengumpulan data dalam penelitian ini adalah dengan menggunakan metode

Design Thinking yang bertujuan untuk mencari permasalahan apa yang harus dicarikan solusi penyelesaianya, tahapan Design Thinking ini berisi 4 tahap yang pertama yaitu:

1. Understanding dalam tahapan ini bertujuan untuk mecari data dan informasi secara lengkap serta melakukan pemetaan sehingga memunculkan beberapa masalah utama kemudian dicari solusi penyelesaianya;

2. Ideate dalam tahapan ini solusi yang tadi sudah dimunculkan pada tahapan understanding dikembangkan lagi sehingga memunculkan banyak solusi solusi yang dapat dipertimbangkan dan digunakan;

3. Prototype hal yang dilakukan pada tahapan ini adalah mencoba untuk merealisasikan ide desain yang sudah ada untuk dapat diuji langsung;

4. Test yang dilakukan untuk mengetahui apakah ide desain yang sudah ada mampu diterima oleh pengguna, dengan cara penggunaan langsung atau mengimplementasikan desain secara visual, tentunya pada tahapan ini memunculkan banyak kritik dan saran yang dapat kita gunakan untuk pengembangan ke desain selanjutnya. 


\section{B. Metode Analisis Data}

Metode analisa data yang digunakan pada penelitian ini merupakan suatu tahap untuk mencari atau memperoleh serta mengumpulkan data yang akan digunakan untuk keperluan penelitian, dengan menggunakan metode pendekatan kualitatif deskriptif yaitu melakukan pengamatan dan mengumpulkan hasil serta data yang kemudian dianalisis tetapi juga memaparkan hasil pengamatan nyata di lapangan.

Selain itu juga digunakan metode kualitatif. Data diperoleh dari hasil observasi, wawancara, dokumentasi, dan studi literatur, yang kemudian akan diolah dan dianalisa untuk mendapatkan kesimpulan atas pemecahan masalah yang ada sebagai acuan dalam proses desain.

\section{HASIL PENELITIAN DAN PEMBAHASAN}

Target sasaran penelitian ini adalah Villa di Serangan yang salah satu struktur dan elemen pembentuknya memanfaatkan limbah bekas konstruksi. Atas dasar inilah villa ini diberi nama Wastewood Villa, oleh arsitekturnya sendiri yaitu Bapak Ivan Pudjo Nugroho. Upaya pemanfaatan limbah bekas konstruksi ini beliau lakukan agar dapat mengurangi limbah yang menimbulkan kerusakan lingkungan. Awal mula Bapak Ivan hanya mengumpulkan sisa-sisa bahan bangunan yang tidak terpakai lagi, dari situlah muncul ide untuk pemanfaatan limbah bekas tersebut kedalam pembangunan villa ini.

Setelah peneliti melakukan observasi langsung ke lapangan, maka hal yang ditemukan adalah banyaknya limbah bekas konstruksi bangunan yang dibiarkan di gudang, sedangkan beberapa limbah tersebut masih memiliki nilai guna yang sangat tinggi dan dapat diolah serta dimanfaatkan menjadi sesuatu yang berguna.

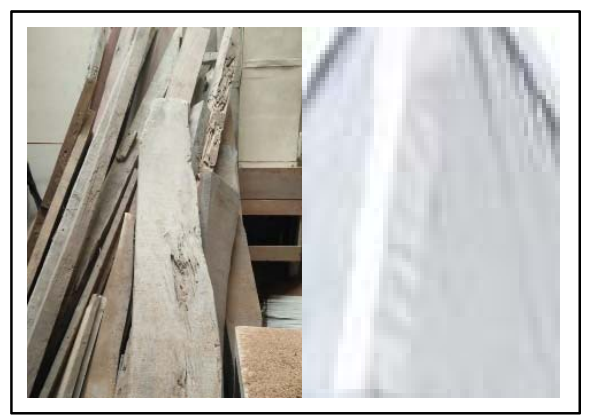

Gambar 1. Limbah Bekas Konstruksi Bangunan di Gudang Sumber: Dokumentasi Penulis (2019)

Dengan melihat adanya permasalahan diatas, maka dibentuklah Villa berbasis material limbah konstruksi yang dapat berpotensi untuk mengurangi pencemaran lingkungan dan menghemat biaya persewaan gudang. Beberapa potongan-potongan material yang dipilih dari berbagai limbah konstruksi untuk dijadikan bangunan Villa antara lain:

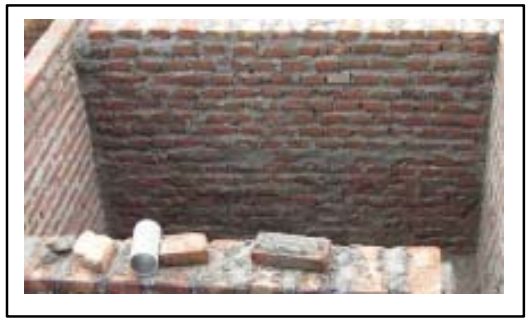

Gambar 2. Batu Bata

Sumber: Dokumentasi Penulis (2019)

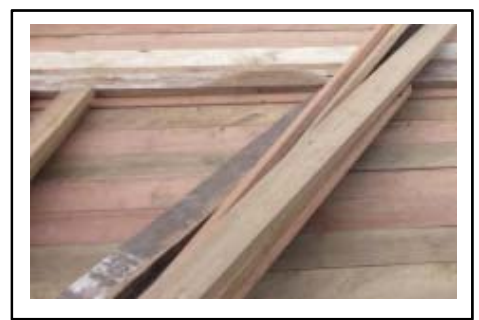

Gambar 3. Kayu Kamper dan Jati Sumber: Dokumentasi Penulis (2019) 
Felicia Wisama, Febriani Elisabeth, Indah Fahroni

Pemanfaatan Limbah Konstruksi menjadi Villa Serbaguna dengan Pendekatan Green Design

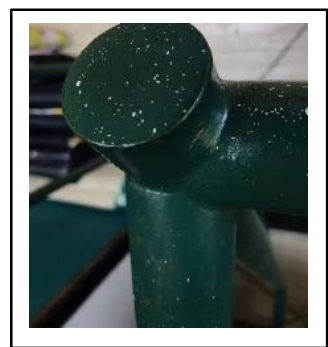

Gambar 4. Besi IWF 150

Sumber: Dokumentasi Penulis (2019)

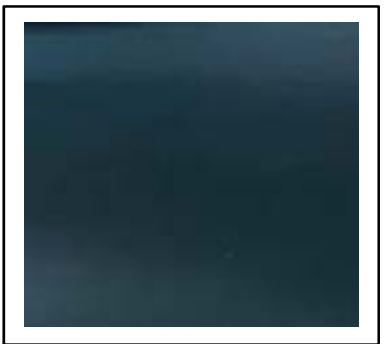

Gambar 5. Terpal Sisa Penutup Truk Konstruksi Sumber: Dokumentasi Penulis (2019)

Tahapan dalam Proses Pembangunan Villa Wastewood:

1. Pembangunan Struktur kerangka kuda-kuda konstruksi rangka baja dengan menggunakan material besi IWF 150 sisa bangunan dan pondasi menggunakan material pecahan batu kali.

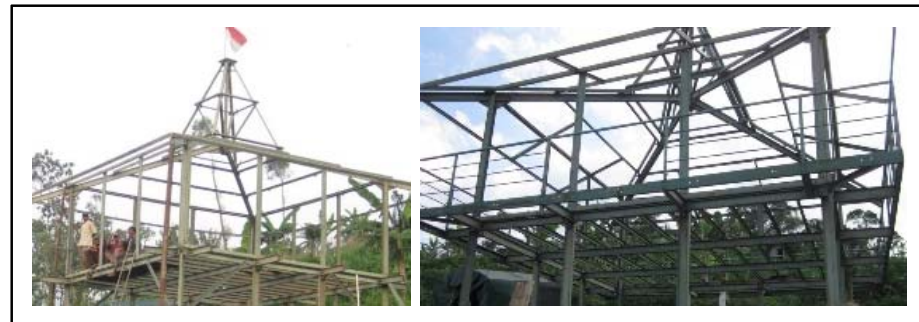

Gambar 6. Konstruksi Atap

Sumber: Dokumentasi Penulis (2019)

2. Pembangunan kerangka pintu menggunakan kayu kamper dengan tinggi 2 meter dan pembangunan penutup railing menggunakan kayu kamper berukuran 9 x 0,5 meter.

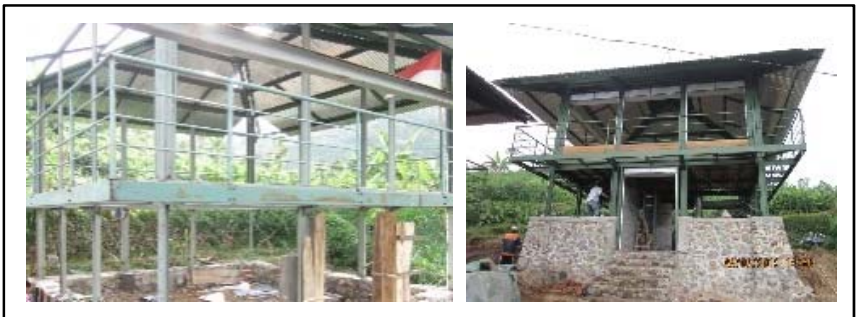

Gambar 7. Konstruksi Dinding Sumber: Dokumentasi Penulis (2019)

3. Pembangunan kerangka lantai 2 dengan menggunakan kayu jati berukuran $3 \times 0,3$ meter.

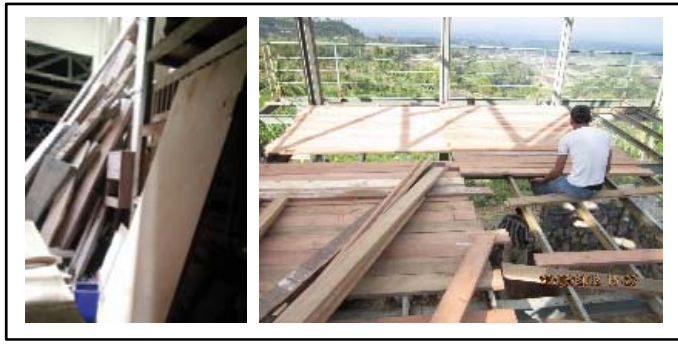

Gambar 8. Konstruksi Lantai Sumber: Dokumentasi Penulis (2019) 
4. Pembangunan dinding dengan kayu kamper berukuran $3 \times 0,3$ meter. Pembangunan plafon dengan menggunakan konstruksi single pada pertemuan kuda-kuda dinding dipersatukan dengan skup sehingga berbentuk limas.

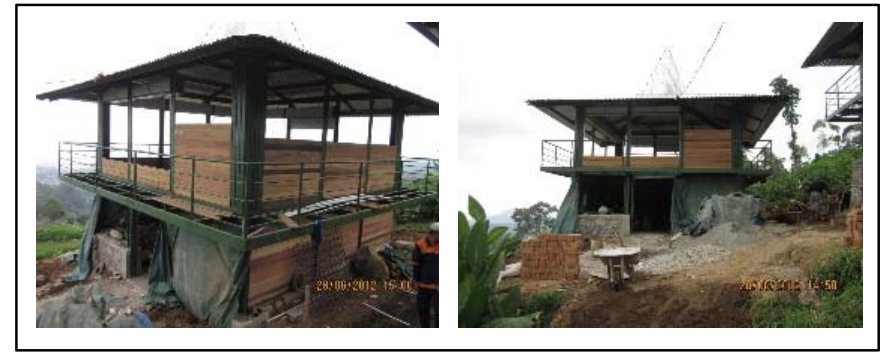

Gambar 9. Konstruksi Dinding Sumber: Dokumentasi Penulis (2019)

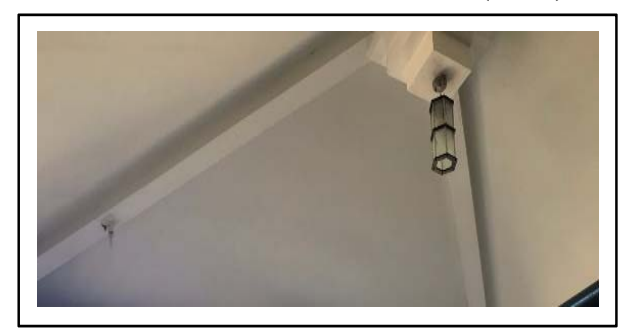

Gambar 10. Konstruksi Plafon

Sumber: Dokumentasi Penulis (2019)

Dengan adanya Wastewood Villa ini, yang berguna untuk mengurangi kerusakan lingkungan dengan memanfaatkan kembali limbah bekas konstruksi, dapat juga untuk mengakomodasi para wisatawan yang akhir-akhir ini gemar melakukan wisata alam puncak gunung. Tidak kalah menarik dengan villa-villa modern lainnya, villa wastewood ini memiliki desain dan ciri khas yang unik dan menarik untuk dirasakan secara langsung oleh wisatawan. Berikut ini tampilan interior dari Wastewood Villa:

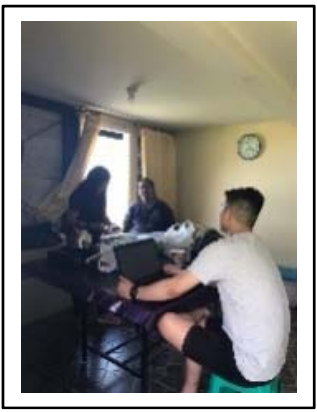

Gambar 11. Situasi Villa

Sumber: Dokumentasi Penulis (2019)

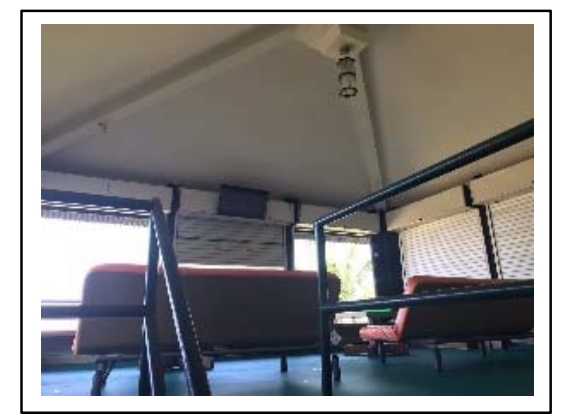

Gambar 12. Ruang Keluarga Sumber: Dokumentasi Penulis (2019)

Jika diamati pada area ruang keluarga terdapat bukaan yang luas pada dinding villa. Tujuannya untuk membantu pencahayaan di siang hari dan jalur masuknya udara, sehingga lebih hemat energi dan ekonomis. Material yang dimanfaatkan pada bidang lantai villa memanfaatkan terpal bekas truk, yang berfungsi sebagai penutup lantai, sedangkan pada bidang dinding memanfaatkan kayu kamper bekas. Dari bukaan luas tersebut juga, para pengguna villa dapat menikmati pemandangan asri yang ada di sekitar villa. 


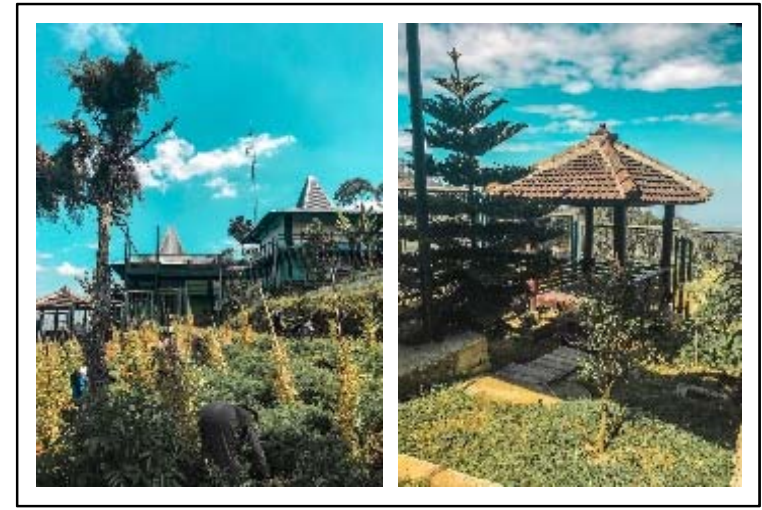

Gambar 13. Suasana Sekitar Villa Sumber: Dokumentasi Penulis (2019)

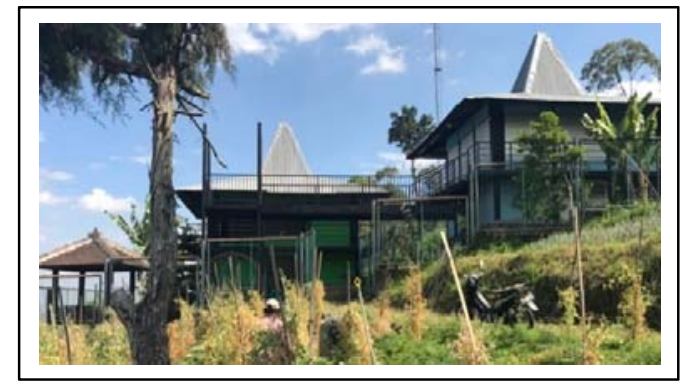

Gambar 14. Tampak Luar Villa Sumber: Dokumentasi Penulis (2019)

Pemanfaatan limbah bekas konstruksi pada Wastewood Villa:

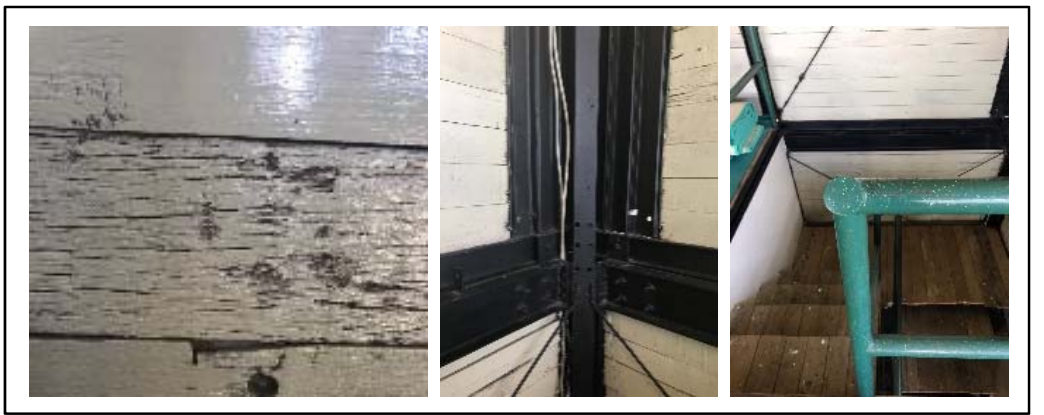

Gambar 15. Limbah Kayu Kalimantan (Potongan Kecil) yang Dimanfaatkan dalam Pembuatan Lantai Villa Sumber: Dokumentasi Penulis (2019)

\section{KESIMPULAN}

Melalui analisa di atas sebuah pemanfaatan kembali material bekas sebagai material utama membuat bangunan adalah langkah yang sangat efektif. Seperti pembahasan diatas, villa yang dibangun menggunakan material limbah konstruksi ini dapat berguna untuk masyarakat dan sebagai penunjang bisnis. Selain itu, adanya villa ini juga bisa mengedukasi masyarakat bahwa limbah konstruksi masih memiliki nilai guna yang sangat tinggi dan berpotensi dimanfaatkan kembali menjadi bangunan ataupun barang yang berguna. Keuntungan lain dari pemanfaatan limbah bekas konstruksi (material bekas) sebagai material utama adalah dapat menekan biaya pembangunan, proses tidak melibatkan proses fisika maupun kimia, serta tidak membutuhkan 
banyak energi dan juga dapat menambah nilai estetika suatu bangunan dengan menggunakan pure material.

\section{DAFTAR PUSTAKA}

Indraguna, Mahesha et. al. (2014). Kajian Manfaat Material Botol Bekas sebagai Elemen Dinding terhadap Kenyamanan Thermal \& Visual Ditinjau dari Aspek Sustainable. Jurnal Reka Karsa. Vol. 2 No. 3. Malang: Jurnal Online Institut Teknologi Nasional.

Ningrum, Dian Suci Wulandari. Penerapan Reuse Material Bekas sebagai Bahan Material pada Bangunan. (Online). (https://www.academia.edu/13090630/PENERAPAN REUSE_MATERIAL_BEKAS_SEBAGAI_BAHAN_MATERIAL_PADA_BANGUN AN, diakses pada tanggal 9 Oktober 2019 jam 18.12)

Soerjani, M. (1984). Present Waste Management in Cities in Indonesia, Conservation \& Recycling. Vol. 7 No. 2-4.

Wulandari, R. (2001). Minimisasi Limbah Konstruksi pada Proyek Rumah Tinggal. unpublished final project report, Civil Engineering Department, Faculty of engineering, University of Indonesia. 
Felicia Wisama, Febriani Elisabeth, Indah Fahroni

Pemanfaatan Limbah Konstruksi menjadi Villa Serbaguna dengan Pendekatan Green Design 